\title{
Organisational Culture and Corporate Performance: Empirical Evidence From Nigeria
}

\author{
Olu Ojo \\ Osun State University, Nigeria
}

\begin{abstract}
The purpose of this research article is to examine various concepts on organisational culture and strives to ascertain the importance of the relationship between organisational culture and corporate performance in a business context. The study adopted survey research design. The population of this study is the entire employees of Nigerian commercial banks. Primary data were used for this study. Data were collected through a questionnaire that was administered to the selected respondents, The two hypotheses proffered were tested and relevant recommendations were made. The conclusion drawn from the study is that organisational culture plays a vital role in an organisation's general performance. This study contributes to organisational culture's literature by showing that employees would commit themselves to organisational goals and work actively in achieving those goals when they buy into cultural norms of the organisation and thus increase organisational performance.
\end{abstract}

\section{Keywords}

Organisational Culture, Employee's Commitment, Corporate Performance

\section{Introduction}

The concept of organisational culture received unusual attention in the late 1980s and early 1990s as management scholars were exploring how and why the American firms failed to compete with their Japanese counterparts. Organisational culture is frequently said to be responsible for all manner of organisational ills and, on occasions, credited with creating positive qualities (Ouchi, 1981; Barney, 1986; Kathryn, 2002; Shani and Lau, 2005). A better understanding of the concept would allow people in organisations to solve problems and improve organisational performance.

According to Brooks (2006), an intimate knowledge and awareness of culture should improve our ability to analyse organisational behaviour in order to manage and lead.

From the statement above, it can be said that research in organisational culture enables ability to analyse organisational behaviour which translates into superior corporate performance. Brooks (2006) insists that despite the emphasis given to the concept of organisational culture for over five decades, there remain considerable debate and contention surrounding the nature of, and the value of studying organisational culture.

Copyright (C) 2010 Victoria University. This document has been published as part of the Journal of Business Systems, Governance and Ethics in both online and print formats. Educational and non-profit institutions are granted a nonexclusive licence to utilise this document in whole or in part for personal or classroom use without fee, provided that correct attribution and citation are made and this copyright statement is reproduced. Any other usage is prohibited without the express permission of the publisher.
The continuous growth in the global nature of business serves as one of the main catalysts for the renewed interest in the study of organisational culture which has now been realised that culture affects the behaviour and success of individuals, teams and organisations (Shani and Lau, 2005). Academic interest in corporate culture is evidenced by the level of 
attention it has received over the last few decades (Ojo, 2009). The relationship between organisational culture and corporate performance has been the subject of abundant research in several fields, including strategic management, organisational behaviour, and industrial and organisational psychology.

While this topic is rich in studies, many researchers (Saffold, 1988; Denison, 1990; Johns and Saks, 2005; Dasanayake and Mahakalanda, 2008) concurred on the fact that there is no agreement on the precise nature of the relationship between organisational culture and corporate performance. In other words, there is no widely accepted causal relationship between organisational culture and corporate performance. The empirical evidences emerging from various studies about the effect of organisational culture on corporate performance have so far yielded mixed results that are inconclusive and contradictory. Because of these contradictory results, the question of whether organisational culture improves or worsens corporate performance is still worthy of further research.

A review of academic literature on the subject of organisational culture and corporate performance reveals that there is dearth of literature on it in developing countries including Nigeria. Thus, it is hoped that this study will fill the existing gaps in the literature especially in the less developed countries in general and Nigeria in particular.

The main rational for this research study is therefore to contribute to the broader research community by enhancing existing knowledge and generating new knowledge within the field of Industrial and Organisational Psychology. Furthermore, this study addresses this topic from Nigerian work context and viewpoint by focusing on the banking industry. In addition, the study will be of immense benefit to a number of people. These include academics who are interested in furthering their knowledge of organisational culture and corporate performance as the results obtained are capable of adding new insights to the present state of knowledge in the field and may therefore be found useful for teaching and for developing a body of management theory. Equally important is the fact that this study will also be of great benefit to practicing managers in banking industry that might be willing to consider the usefulness of the study in managing and strengthening the performance of their companies.

In order to address the issues raised above, the following questions are answered in this study. (1) Does organisational culture has any effect on employee's commitment to corporate goals? (2) In what way does organisational culture affects corporate performance? The primary objective of this study is to assess the impact of organisational culture on corporate performance.

\section{Literature Review}

\section{The Concept of Organisational Culture}

Culture has been called "the way of life for an entire society." The culture of a group can be defined as: "A pattern of shared basic assumptions that the group learned as it solved its problems of external adaptation and internal integration, that has worked well enough to be considered valid and therefore, to be taught to new members as the correct way to perceive, think, and feel in relation to those problems" (Schein, 1990).

In other words, as groups evolve over time, they face two basic challenges: integrating individuals into an effective whole, and adapting effectively to the external environment in order to survive. As groups find solutions to these problems over time, they engage in a kind of collective learning that creates the set of shared assumptions and beliefs we call "culture."

According to Brooks the current fascination with organisational culture began in the 1970s and early 1980s with the works of Peters and Waterman (1982), Deal and Kennedy (1982) among others. In 1952, Jacques referred to culture of a factory as 'its customary and traditional way of thinking and of doing things which is shared and which new members must learn' (Jacques, 1952, cited in Brooks (2006). He argued that culture comprised behaviours, attitudes, customs, values, beliefs, and the less conscious conventions and taboos. 


\section{Evolution of Organisational Culture Concept}

The concept of organisation culture received attention in the late 1980s and early 1990s as management scholars were exploring how and why the American companies failed to compete with their Japanese counterparts. The concept of a national culture was not a sufficient explanation to this phenomenon. Instead, a model was needed that allowed for differentiation between organisations within a culture (Schein, 1990). This ultimately resulting to the concept of organisational culture. According to Baker (2002) organisational culture became a business phenomenon in the early 1980s, triggered by four influential books:

- Ouchi (1981) Theory Z: How American Business Can Meet the Japanese Challenge

- Pascale and Athos (1982) The Art of Japanese Management: Applications for American Executives

- Deal and Kennedy (1982) Corporate Cultures: The Rites and Rituals of Corporate Life

- Peters and Waterman (1982) In Search of Excellence: Lessons from America's Best Run Companies.

All these books suggested that corporate culture is a key to organisational performance and that corporate culture could be managed to improve a company's competitive advantage. They provided pragmatic prescriptions to American business leaders desperate with the increasing competition from Japanese manufacturers.

Attention to organisational culture lost ground as organisational science, and social science in general, became increasingly quantitative. To the extent that research on organisational culture survived, its focus shifted to its more measurable aspects, particularly employee attitudes and perceptions and/or observable organisational conditions thought to correspond to employee perceptions. This research, referred to as organisational climate studies, was prominent during the 1960s and 1970s (Denison, 1990).

The renewed interest in organisational culture that emerged in the late 1970s and resulted in the four books mentioned above suggested that a deeper, more complex anthropological approach was necessary to understand crucial but largely invisible aspects of organisational life.

\section{Characteristics of Organisational Culture}

According to Hodgetts and Luthans (2003) a number of important characteristics are associated with an organisation's culture.

1. Observed behavioural regularities, as typified by common language, terminology and rituals.

2. Norms as reflected by things such as the amount of work to be done and the degree of cooperation between management and employees.

3. Dominant values that the organisation advocates and expects participants to share, such as high product or service quality, low absenteeism, and high efficiency.

4. A philosophy that's set forth in the Multinational corporations, beliefs regarding how employees and customers should be treated.

5. Rules that dictate the do's and don'ts of employee behaviour relating to areas such as productivity, customer relations, and intergroup cooperation.

6. Organisational climate or the overall atmosphere of the enterprise as reflected by the way that participants interact with each other, conduct themselves with customers, and feel about the way they are treated by higher-level management.

Besides, Schein (1992) suggests that organisational culture is even more important today than it was in the past. Increased competition, globalisation, mergers, acquisitions, takeovers, buyouts, alliances, and various workforce developments have created a greater need for the following:

1. Coordination and integration across organisational units in order to improve efficiency, quality, and speed of designing, manufacturing, and delivering products and services. 
2. Product, Strategy and Process innovations and the ability to successfully introduce new technologies, such as information technology.

3. Effective management of dispersed work units and increasing workforce diversity.

4. Cross-cultural management of global enterprises and/or multi-national partnerships.

5. Construction of meta- or hybrid- cultures that merge aspects of cultures from what were distinct organisations prior to an acquisition or merger.

6. Management of workforce diversity.

7. Facilitation and support of teamwork.

In addition to a greater need to adapt to these external and internal changes, organisational culture has become more important today as the world is geared towards knowledge based economy. Maximising the value of employees as intellectual assets requires a culture that promotes their intellectual participation and facilitates both individual and organisational learning, new knowledge creation and application, and the willingness to share knowledge with others (Dasanayaka and Mahakalanda, 2008).

These characteristics are not intended to be all inclusive but they do help to illustrate the nature of organisational culture.

\section{Organisational Culture and Performance}

Several writers argue that a strong corporate culture is good for business because it serves three important functions discussed below.

First, corporate culture is a deeply embedded form of social control that influences employee decisions and behaviour.

Second, corporate culture is the social glue that bonds people together and makes them feel part of the organisational experience. This social glue is increasingly important as a way to attract new staff and retain top performers.

Finally, corporate culture assists the sense-making process. In other words, it helps employees understand organisational events and employees can communicate more efficiently and effectively thereby, reaching higher levels of cooperation with each other because they share common mental models of realities (McShane and Glinow, 2005).

The powerful, pervasive role culture plays in shaping organisational life lends plausibility to speculations that cultural factors may be linked with exceptional levels of organisational performance. A commonly hypothesised link suggests that if an organisation's culture is to contribute to or enhance performance, it must be both "strong" and possess distinctive "traits": particular values, beliefs, and shared behaviour patterns. Some scholars have claimed that positive cultural traits boost performance in proportion to the strength of their manifestation. This view has been called the strong culture hypothesis. (Denison, 1984) cited in Saffold (1988).

Strong, powerful cultures have been hailed as keys to improved performance. Strong culture has almost always been the driving force behind continued success in businesses. Strong culture firms are said to generate an almost tangible social force field of energy that empowers employees and drives the organisation toward superior performance. Several management researchers have connected strongly shared values with commitment, self-confidence, ethical behaviour, and reduced job stress (Saffold, 1988). He further states that studies on organisational culture tend to emphasise a single, unitary organisational culture. Multiple subcultures, however, appear to be the rule, unitary cultures the exception in several companies of cultural control in there exists highly complex interrelationships among the plant's or branch's subcultures. Organisation development efforts, for example, may be often hindered rather than helped by strong, widely shared values. This is because the management and labour may represent powerful subcultures that are committed to highly salient but competing value systems. 
It could be deduced from the above explanations that some firms may obtain sustained superior financial performance from their organisational cultures; firms without such cultures cannot expect to engage in managerial activities that generate such performance.

According to Barney (1986) in order for a firm's culture to provide sustained competitive advantages, and thus, by implication, be a source of sustained superior financial performance, three conditions must be met First, the culture must be valuable; it must enable a firm to do things and behave in ways that lead to high sales, low costs, high margins, or in other ways add financial value to the firm. Because superior financial performance is an economic concept, culture, to generate such performance, must have positive economic consequences. Second, the culture must be rare; it must have attributes and characteristics that are not common to the cultures of a large number of other firms. Finally, such a culture must be imperfectly imitable; firms without these cultures cannot engage in activities that will change their cultures to include the required characteristics, and if they try to imitate these cultures, they will be at some disadvantage (reputational, experience, etc.) compared to the firm they are trying to imitate.

Barney goes on to state that superior financial performance can be either temporary or sustained. Temporary superior performance is the result of competitive dynamics widely described in microeconomics. Suppose a particular firm is able, for any of a variety of reasons, to obtain superior financial performance. Other firms, observing this, typically will seek to obtain this same level of performance by duplicating whatever makes a successful firm successful. Imitation increases the competition facing the initially successful firm, reduces margins, and decreases the level of financial performance.

Deal and Kennedy (1982) state that cultures, both weak and strong have powerful influence on organisational behaviour, but in strong cultures "everyone knows the goals of the corporation, and they are working for them. Thus, in a strong culture employees' goals are aligned with management's goals; in a weak culture members' goals are counter to management's direction or perhaps simply scattered and divergent.

It could be drawn from all the explanations above that firms with sustained superior financial performance typically are characterised by a strong set of core managerial values that define the ways they conduct business. It is these core values (about how to treat employees, customers, suppliers, and others) that foster innovativeness and flexibility in firms; when they are linked with management control, they are thought to lead to sustained superior financial performance.

Furthermore, Saffold (1988) identifies two relevant facts: first, culture can shape organisational processes, but processes also act to create and modify culture. Culture's contribution to performance is a consequence of this ever-evolving interaction. Second, it is likely that culture's link to performance is considerably less straightforward than many studies imply.

The figure below shows some elements and relationships of a culture-performance framework. 
Figure 2: Elements and Relationship of Culture-Performance Framework

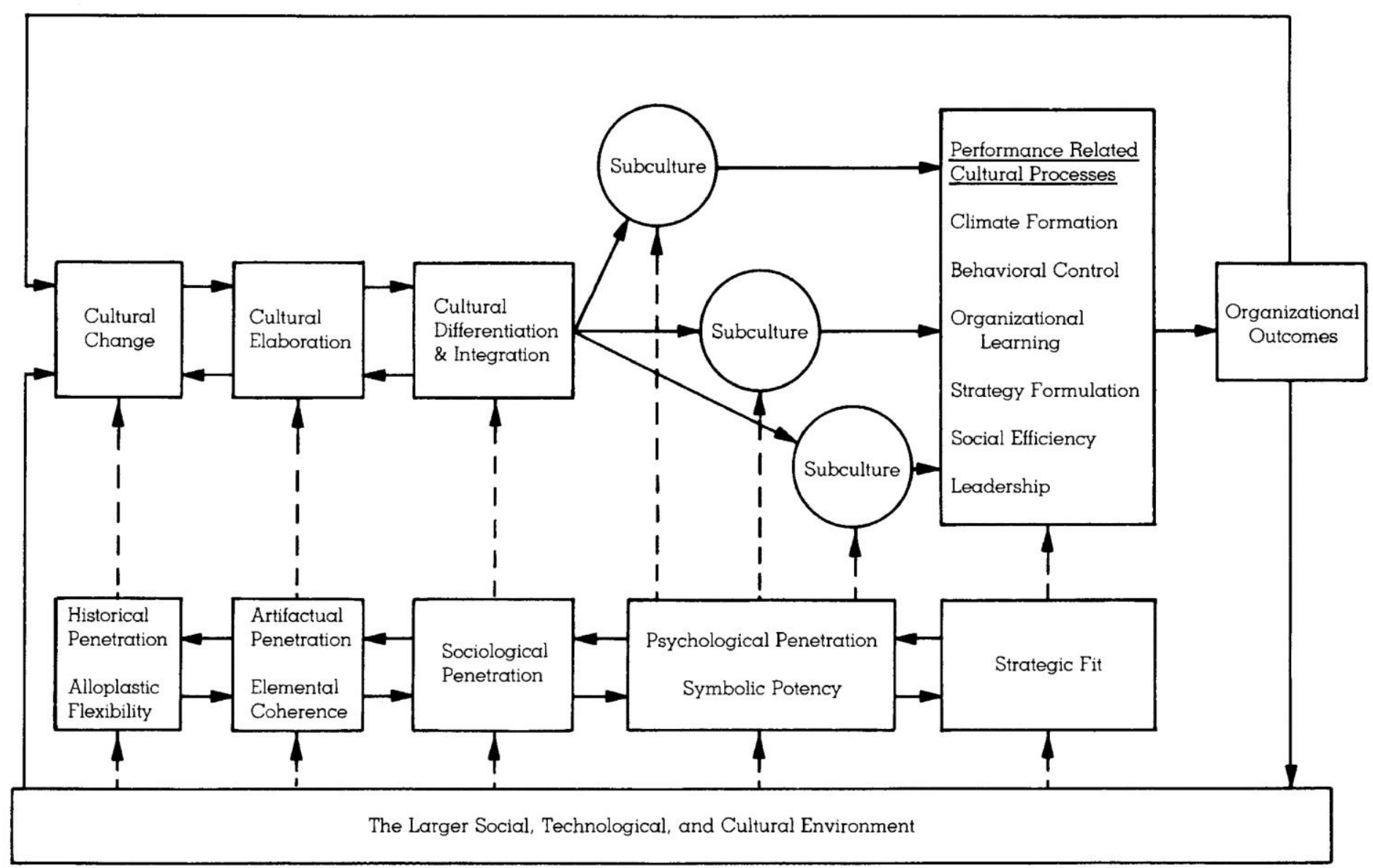

Source: Adapted from Saffold, G.S. 1988)

According to McShane and Glinow (2005), when a firm's strong culture is misaligned with its environment, it is unable to effectively serve customers and other dominant stakeholders. Furthermore, these strong cultures would lock decision makers into mental models that blind them to new opportunities and unique problems. Thus, strong cultures might cause decision makers to overlook or incorrectly define subtle misalignments between the organisation's activities and the changing environment.

\section{Methodology}

The design of this study is the survey research design. The study population of this research work was made up of senior staff, directors, and managers of the Nigerian banks. Owing to the widespread of the network of branches of these banks all over the country, it is therefore impossible to carry out this research using the whole population. The population of this study is the entire employees of Nigerian commercial banks. For effective coverage and lower cost, stratified sampling technique was used to select the participating banks. These banks were stratified into two strata based on the year they were established. Thus we have "old" generation banks and "new" generation banks. From each stratum, two banks were randomly selected. The employees in the selected banks were stratified into three strata: senior staff, directors, and managers. 30 respondents each were selected from senior staff and directors' stratum while 20 respondents were selected from manager's stratum. In all, 80 respondents constitute our sample size. In conducting this study the researcher ensured that data collection method match the research objective--to explore the relationship between organisational culture and corporate performance in Nigerian banking industry. Primary data were used for this study. Our data were collected through a questionnaire that was administered to the selected respondents. The questionnaire was titled "The Strategic Role of Organisational Culture on Corporate Performance Questionnaire". 
However, only 72 out of 80 respondents filled in and returned their questionnaire and were used for final analysis in this study. Data collected from the study were collated and analysed using descriptive analysis to obtain the basic statistics that describe the variables in the questionnaire. The information gathered from the research is presented in tabular form and data were sorted into different categories of rows and columns. Furthermore, all the hypotheses were tested using a parametric t-test with the aids of SPSS.

\section{Research Hypothesis}

\section{Hypothesis 1}

$\mathbf{H}_{1:}$ Employees believe that there is a correlation between organisational culture and employee's commitment to corporate goals.

\section{Hypothesis 2}

$\mathbf{H}_{1:}$ Employees believe that there is a correlation between organisational culture and corporate performance.

\section{Data Presentation and Analysis}

This section focuses mainly on the presentation, analysis and interpretation of primary data collected with the aid of a structured research questionnaire. The data collected were analysed using the Statistical Package for Social Sciences (SPSS) version 15.

The table below gives a summary of the rate of return of questionnaire and participation level of the respondents.

Table 1: Respondents' Response Rate

\begin{tabular}{|l|l|l|}
\hline \multicolumn{1}{|c|}{ Response } & \multicolumn{1}{|c|}{ Number of respondents } & \multicolumn{1}{c|}{ Percentage (\%) } \\
\hline Returned & 72 & $90 \%$ \\
\hline Not returned & 8 & $10 \%$ \\
\hline Total distributed & 80 & $100 \%$ \\
\hline
\end{tabular}

Source: Field Survey, 2009

A total of 80 copies of the questionnaires were administered selected respondents. Of these, 72 copies $90 \%$ were adequately filled returned and used in this analysis while 8 copies of the questionnaires representing $10 \%$ were not returned. The return rate indicates that overwhelming majority of the respondents cooperated with the researcher in the process of data gathering.

Table 2: Does Organisational Culture Affects Employee Productivity

\begin{tabular}{|ll|l|l|l|l|}
\hline & & & & & \\
& & Frequency & Percent & Valid Percent & Cumulative Percent \\
\hline Valid & Yes & 69 & 95.8 & 97.2 & 97.2 \\
& No & 2 & 2.8 & 2.8 & 100.0 \\
& Total & 71 & 98.6 & 100.0 & \\
Missing & System & 1 & 1.4 & & \\
Total & & $\mathbf{7 2}$ & $\mathbf{1 0 0 . 0}$ & & \\
\hline
\end{tabular}

Source: Field Survey, 2009

From table 2 above, the responses presented reveal that $97.2 \%$ of the respondents believe that the culture in their organisation affects employees' productivity as well as corporate performance; while only $2.8 \%$ of the respondents believe otherwise. One of the respondents $(1.4 \%)$ however did not respond to the question. 
Table 3: There is a correlation between organisational culture and employees' commitment to corporate goals.

\begin{tabular}{|ll|l|l|l|l|}
\hline & & Frequency & Percent & Valid Percent & Cumulative Percent \\
\hline Valid & Strongly agree & 12 & 16.7 & 16.9 & 16.9 \\
& Agree & 24 & 33.3 & 33.8 & 50.7 \\
& Indifferent & 17 & 23.6 & 23.9 & 74.6 \\
& Strongly disagree & 6 & 8.3 & 8.5 & 83.1 \\
& Disagree & 12 & 16.7 & 16.9 & 100.0 \\
& Total & 71 & 98.6 & 100.0 & \\
Missing & System & 1 & 1.4 & & \\
Total & & $\mathbf{7 2}$ & $\mathbf{1 0 0 . 0}$ & & \\
\hline
\end{tabular}

Source: Field Survey, 2009

Table 3 above reveals that $16.7 \%$ of the respondents agreed that there is a correlation between organisational culture and employees' commitment to corporate goals. In other words, we can say that workers who have internalised the organisation's culture function better in terms of goals achievement. $33.3 \%$ of the respondents agree, $23.6 \%$ of the respondents are indifferent to the statement, $8.3 \%$ of the respondents strongly disagree, and $16.7 \%$ of the respondents disagree with the statement. We are unable to get the response of one respondent. From the above, we can marginally say that workers who have internalised themselves with organisational culture will achieved better performance and be committed to corporate goals than their colleagues who did not internalised organisational culture.

Table 4: There is a Correlation between Organisational Culture and Corporate Performance

\begin{tabular}{|ll|l|l|l|l|}
\hline & Frequency & Percent & Valid Percent & Cumulative Percent \\
\hline Valid & Strongly agree & 18 & 25.0 & 25.0 & 25.0 \\
& Agree & 46 & 63.9 & 63.9 & 88.9 \\
& Indifferent & 2 & 2.8 & 2.8 & 91.7 \\
& Strongly disagree & 1 & 1.4 & 1.4 & 93.1 \\
& Disagree & 5 & 6.9 & 6.9 & 100.0 \\
& Total & $\mathbf{7 2}$ & $\mathbf{1 0 0 . 0}$ & $\mathbf{1 0 0 . 0}$ & \\
\hline
\end{tabular}

Source: Field Survey, 2009

Here, responses as to whether there is a relationship between organisational culture and corporate performance are presented in table 4 above. The table reveals that $25.0 \%$ of the respondents strongly agreed, another $63.9 \%$ of the respondents agreed to this assertion. $2.8 \%$ of the respondents are indifferent to the statement. $1.4 \%$ of the respondents strongly disagree while remaining $6.9 \%$ of respondents disagree with the statement. The inference that can be drawn here is that there is a correlation between organisation culture and corporate performance.

Table 5: Employees commit themselves to actively achieving organisational goals when they buy into cultural norms of the organisation

\begin{tabular}{|ll|l|l|l|l|}
\hline & & Frequency & Percent & Valid Percent & Cumulative Percent \\
\hline Valid & Strongly agree & 21 & 29.2 & 29.6 & 29.6 \\
& Agree & 43 & 59.7 & 60.6 & 90.1 \\
& Indifferent & 5 & 6.9 & 7.0 & 97.2 \\
& Disagree & 2 & 2.8 & 2.8 & 100.0 \\
& Total & 71 & 98.6 & 100.0 & \\
Missing & System & 1 & 1.4 & & \\
Total & & $\mathbf{7 2}$ & $\mathbf{1 0 0 . 0}$ & & \\
\hline
\end{tabular}

Source: Field Survey 2009 
In table 5 above, respondents were required to state whether employees commit themselves to actively achieving organisational goals when they buy into cultural norms of their organisation. The responses presented reveal that $29.2 \%$ of the respondents strongly agreed, $59.7 \%$ of the respondents agreed to this assertion. However, $6.9 \%$ of respondents are indifferent to the statement, while $2.8 \%$ of respondents disagreed. $1.4 \%$ of the respondents did not respondent to the statement. Thus, we can say that employees commit themselves to actively achieving organisational goals when they buy into cultural norms of the organisation. Hence, they enhance organisational performance.

\section{Testing of Hypotheses and Discussion of Results}

The hypotheses for this study are tested here using the non-parametric chi-square test and a parametric $\mathrm{t}$ - test. Below are the discussions of the results obtained.

\section{Hypothesis 1}

$\mathbf{H}_{1}$ : Employees believe that there is a correlation between organisational culture and employee's commitment to corporate goals.

One-Sample Statistics

\begin{tabular}{|l|r|r|r|c|}
\hline & $\mathrm{N}$ & Mean & $\begin{array}{c}\text { Std. } \\
\text { Dev at on }\end{array}$ & $\begin{array}{c}\text { Std. Error } \\
\text { Mean }\end{array}$ \\
\hline $\begin{array}{l}\text { There is a correlation between } \\
\begin{array}{l}\text { Organizational culture and } \\
\text { Employees, commitment to } \\
\text { Corporate goals. }\end{array}\end{array}$ & 72 & 2.01 & .986 & .116 \\
\hline
\end{tabular}

Interpretation: Where 1 represents strongly agree, 2 represents agree, 3 represents indifferent, 4 represents strongly disagree, and 5 represents disagree. Therefore, the mean of 2.01 shows the average response indicates the respondents agree that there is a correlation between organisational culture and employee's commitment to corporate goals.

One-Sample Test

\begin{tabular}{|c|c|c|c|c|c|c|}
\hline & \multicolumn{6}{|c|}{ Test Va ue $=0$} \\
\hline & \multirow[b]{2}{*}{$\mathrm{t}$} & \multirow[b]{2}{*}{ df } & \multirow[b]{2}{*}{ S g. (2-ta ed) } & \multirow{2}{*}{$\begin{array}{c}\text { Mean } \\
\text { D fference }\end{array}$} & \multicolumn{2}{|c|}{$\begin{array}{l}95 \% \text { Conf dence } \\
\text { Interva of the } \\
\text { D fference }\end{array}$} \\
\hline & & & & & Lower & Upper \\
\hline $\begin{array}{l}\text { There is a correlation between } \\
\text { Organisational culture and } \\
\text { Employees' commitment } \\
\text { to corporate goals. }\end{array}$ & 17.336 & 71 & .000 & 2.014 & 1.78 & 2.25 \\
\hline
\end{tabular}

Interpretation: This is a two tailed test with $\mathrm{d}$. $\mathrm{f} .=72-1$. The statistical value for 0.05 at 71 degree of freedom is 1.99 and the calculated value $\mathrm{t}=17.336$ is greater than the tabulated value of 1.99 , we accept the alternative hypothesis $\left(\mathrm{H}_{1}\right)$. This implies that organisational culture is positively correlated to employee commitment to corporate goals.

\section{Hypothesis 2}

$\mathbf{H}_{1:}$ Employees believe that there is a correlation between organisational culture and corporate performance. 
One-Sample Statistics

\begin{tabular}{|l|r|r|r|c|}
\hline & $\mathrm{N}$ & Mean & Std. Dev at on & $\begin{array}{c}\text { Std. Error } \\
\text { Mean }\end{array}$ \\
\hline $\begin{array}{l}\text { There is correlation } \\
\text { between organizational } \\
\text { culture \& corporate performance }\end{array}$ & 71 & 1.99 & 1.049 & .124 \\
\hline
\end{tabular}

Interpretation: Where 1 represents strongly agree, 2 represents agree, 3 represents indifferent, 4 represents strongly disagree, and 5 represents disagree. Therefore, the mean of 1.99 shows the average response indicates that the respondents agree that organisational culture impacts corporate performance positively. Thus, there is a correlation between organisational culture and corporate performance.

One-Sample Test

\begin{tabular}{|c|c|c|c|c|c|c|}
\hline & \multicolumn{6}{|c|}{ Test $\mathrm{Va}$ ue $=0$} \\
\hline & \multirow[b]{2}{*}{$\mathrm{t}$} & \multirow[b]{2}{*}{ df } & \multirow[b]{2}{*}{ S g. (2-ta ed) } & \multirow{2}{*}{$\begin{array}{c}\text { Mean } \\
\text { D fference }\end{array}$} & \multicolumn{2}{|c|}{$\begin{array}{l}\text { 95\% Conf dence } \\
\text { Interva of the } \\
\text { D fference }\end{array}$} \\
\hline & & & & & Lower & Upper \\
\hline $\begin{array}{l}\text { There is a correlation } \\
\text { between organizational culture } \\
\text { and corporate performance }\end{array}$ & 15.956 & 70 & .000 & 1.986 & 1.74 & 2.23 \\
\hline
\end{tabular}

Interpretation: This is a two tailed test with d. f. $=71-1$. The statistical value for $\mathrm{t}$ at 0.05 and 70 degree of freedom is 1.99 and the calculated value of $t=15.956$. Since the calculated value of $t$ (15.956) is greater than the tabulated value of $t$ which is 1.99 , we accept the alternative hypothesis $\left(\mathrm{H}_{1}\right)$. This implies that there is a correlation organisational culture and corporate performance.

From the data obtained and analysed, it was discovered that:

i. Proper organisational culture is performance driven which is supported by the employees' responses to whether organisation culture promotes employees' commitment, encourages participation and reinforces their effectiveness and productivity. In essence, there is a correlation between organisational culture and corporate performance. This answers one of the questions posed in the first part of this research. It was also proven after testing the relevant hypothesis.

ii. The study further reveals that the values imbibed by employees' overtime are reflected in the way they think and act.

iii. The result from table 5 reveals that a large percentage of the respondents agree that employees commit themselves to actively achieving organisational goals when they buy into cultural norms of their organisation.

iv. From statistical analysis derived from testing the hypothesis one, the calculated value $t=17.336$ is greater than the tabulated value of 1.99 ; we therefore accept the alternative hypothesis $\left(\mathrm{H}_{1}\right)$. This implies that organisational culture affects employee commitment to corporate goals.

v. Finally, from our test of hypothesis two, the statistical value for 0.05 at 70 degree of freedom is 1.99 and the calculated value of $t=15.956$. Since the calculated value of $t(15.956)$ is greater than the tabulated value of 1.99 , we accept the alternative hypothesis $\left(\mathrm{H}_{1}\right)$. This implies that there is a correlation between organisational culture and corporate performance.

\section{Conclusion}

In this study, the researcher examines the impact of organisational culture on corporate performance with evidence from Nigerian banking industry. Questionnaires were administered to respondents who 
were randomly selected from the study population to find out their opinions and views on whether organisational culture has an impact on corporate performance.

Judging from the various computations, analyses and findings, resulting from data collected for this study, the results revealed some vital facts which our conclusions are based. One, of the things we can deduce from this study is that organisational culture is very important in every business entity and that it is correlated to corporate performance. Besides, organisational culture affects the level of employee's commitment to corporate goals in a positive way.

This study shows that there is a positive relationship between organisational culture and corporate performance.

Considering the high percentage of respondents in favour of the two hypotheses, we can infer that organisational culture plays vital roles in corporate performance. This research has been able to describe and evaluate the effects of various dimensions of organisational culture to explain why some organisations outperform others.

\section{Recommendations}

The following recommendations are made to the management of case study companies and other organisations that are interested in modifying their culture in order to improve their general performance.

Every individual has different culture and beliefs that he works with and when he joins an organisation that has a completely different culture and beliefs from his own, he should be allowed to internalise himself first with the organisation's culture and values to know whether he can cope with them or not. It is the ability of the employee to cope with the organisations culture that will determine his commitment to corporate goals.

In cases where an organisational culture must be changed, employees must first of all be notified and made to learn the modification of the old culture as this will affect their performance as well as the general performance of the organisation.

Organisational culture must be binding on all member and staff of the company as this will encourage uniformity among members of the organisation and thus enhance commitment and group efficiency.

\section{References}

Baker, Kathryn A (2002) Organizational Culture [online] Available from: http://www.au.af.mil/au/awc/awcgate/doe/benchmark/11-Organizational Culture. PDF [Accessed on $15 / 09 / 2009$ ]

Barney, J. B. (1986). Organizational Culture: Can It Be a Source of Sustained Competitive Advantage. The Academy of Management Review, Vol. 11, No.3. pp. 656-665.

Brooks, I. (2006). Organizational Behaviour: Individuals, Groups and Organisation. Essex: Pearson Education Limited.

Dasanayake, S. W. S.B. and Mahakalanda I. (2008) A Literature Survey on Organizational Culture and Innovation, I Mehran Nejati . Azadeh Shafaei . Mostafa Nejatin (Eds.) Issues in Global Business and Management Research: Proceedings of the 2008 International Online Conference on Business and Management (IOCBM 2008) Florida: Boca Raton, Florida pp. 539-550.

Deal, T.E. and Kennedy, A.A. (1982). Corporate Cultures: The Rites and Rituals of Corporate Life. Reading, Mass.: Addison-Wesley Publishing Co.

Denison, D. R. (1984). Bringing Corporate Culture to the Bottom Line. Journal of Organizational Dynamics, 13(2):4-22.

Denison, D. R. (1990). Corporate Culture and Organizational Effectiveness. New York: John Wiley \& Sons.

Hodgetts and Luthans, F. (2003) International Management: Culture, Strategy, and Behaviour. New York, McGraw-Hill/Irwin, Fifth Edition.

Johns, G. and Saks, A. M. (2005). Organizational Behaviour: Understanding and Managing Life at Work. Toronto: Pearson Education Canada Inc. 
McShane, S. L. and Glinow, M. A. (2005). Organizational Behaviour: Emerging Realities for Workplace Revolution. New York: McGraw-Hill, International Edition.

Ojo, O. (2009). Impact Assessment of Corporate Culture on Employee Job Performance. Business Intelligence Journal, Vol. 2, No. 2. pp. 388-397.

Ouchi, W. G. (1981). Theory Z: How American Business Can Meet the Japanese Challenge. Reading MA: Addison-Wesley Publishing Co.

Pascale, R. and Anthos, A. (1982). The Art of Japanese Management: Applications for American Executives. New York: Simon \& Schuster.

Peters, T. and Waterman, R. (1982). In Search of Excellence. New York: Harper and Row.

Saffold, G. S. (1988). Culture Traits, Strength, and Organizational Performance: Moving beyond Strong Culture. The Academy of Management Review, Vol. 13, No. 4. pp. 546-558.

Schein, E. H. (1990). Organizational Culture, American Psychologist, 43 (2), pp.109-119.

Schein, E. H. (1992). Organizational Culture and Leadership (2nd Ed.). San Francisco: Jossey- Bass.

Shani, A. B. and Lau, J. B. (2005). Behaviour in Organizations: An Experiential Approach. ( $8^{\text {th }}$ ed), New York: McGraw-Hill Irwin 